E-JURNAL EKONOMI DAN BISNIS UNIVERSITAS UDAYANA
Available online at https://ojs.unud.ac.id/index.php/EEB/index
Vol. 10 No. 8, August 2021, pages: 664-673
e-ISSN: 2337-3067

\title{
MODAL SOSIAL SEBAGAI UPAYA KEBERLANGSUNGAN USAHA DITENGAH PANDEMI COVID-19 (STUDI KASUS PADA DEBITUR ULTRA MIKRO (UMI) PT. PEGADAIAN (PERSERO) AREA LAMPUNG)
}

\author{
Rini Aprilia $^{1}$ Toto Gunarto $^{2}$ Arivina Ratih Yanti Taher ${ }^{3}$
}

\begin{tabular}{|c|c|}
\hline Article history: & Abstract \\
\hline $\begin{array}{l}\text { Submitted: } 18 \text { April } 2021 \\
\text { Revised: } 17 \text { Mei } 2021 \\
\text { Accepted: } 23 \text { Mei } 2021\end{array}$ & $\begin{array}{l}\text { Social capital is conceptually a relational relationship obtained } \\
\text { from social interaction between ultra-micro enterprise. Trust indicates } \\
\text { that there is a network that shows a link between individuals or groups } \\
\text { that interact with each other continuously so that a trust between } \\
\text { members is formed. The network that generates benefits that lead to } \\
\text { interdependence between members. Values and norms become the basis }\end{array}$ \\
\hline $\begin{array}{l}\text { Keywords: } \\
\text { Social capital; } \\
\text { Ultra micro enterprise; } \\
\text { Sustainability; }\end{array}$ & $\begin{array}{l}\text { of the formation of social capital because it becomes the basis in the } \\
\text { formation of a reciprocal relationship between individuals or groups. The } \\
\text { elements contained in social capital that has the potential to be the efforts } \\
\text { of businesses in maintaining their business. Respondents in this study } \\
\text { numbered } 85 \text { customers, selected using random sampling. Hypothesis } \\
\text { testing is conducted with multiple regression analysis. The results of this } \\
\text { study are social capital positive and significant influence on the business } \\
\text { sustainability of ultra micro debtors PT. Pegadaian (Persero) area } \\
\text { Lampung. }\end{array}$ \\
\hline Kata Kunci: & Abstrak \\
\hline $\begin{array}{l}\text { Koresponding: } \\
\text { Universitas Lampung, } \\
\text { Lampung, Indonesia } \\
\text { Email: } \\
\text { aprili1009.mie19@gmail.com }\end{array}$ & $\begin{array}{l}\text { Modal sosial adalah konseptual suatu hubungan relasional yang } \\
\text { didapat dari interaksi sosial antar pelaku usaha ultra mikro. Kepercayaan } \\
\text { menunjukkan bahwa terdapat suatu jaringan yang memperlihatkan suatu } \\
\text { link antar individu atau kelompok yang saling berinteraksi secara kontinu } \\
\text { sehingga terbentuk suatu kepercayaan antar anggota. Jaringan tersebut } \\
\text { yang menimbulkan manfaat sehingga menimbulkan saling ketergantungan } \\
\text { antara anggota. Norma atau nilai merupakan landasan dasar membentuk } \\
\text { modal sosial kerena merupakan dasar terbentuknya suatu hubungan } \\
\text { timbal balik antara kelompok atau individu. Unsur-unsur yang terdapat } \\
\text { pada modal sosial itulah yang berpotensi menjadi upaya pelaku usaha } \\
\text { dalam mempertahankan usahanya. Responden dalam penelitian ini } \\
\text { berjumlah } 85 \text { nasabah, dipilih menggunakan metode probability dengan } \\
\text { teknik random sampling. Pengujian hipotesis dilakukan dengan analisis } \\
\text { regresi berganda. Adapun hasil penelitian ini adalah modal sosial } \\
\text { berpengaruh positif dan signifikan terhadap keberlangsungan usaha } \\
\text { debitur ultra mikro PT. Pegadaian (Persero) area Lampung. }\end{array}$ \\
\hline
\end{tabular}

Universitas Lampung, Lampung, Indonesia ${ }^{2,3}$ 


\section{PENDAHULUAN}

Pembiayaan Ultra Mikro (UMi) adalah program lanjutan dari program bantuan sosial dengan tujuan kemandirian usaha yang memfokuskan usaha mikro yang berada di lapisan terbawah, yang belum dapat difasilitasi perbankan melalui program Kredit Usaha Rakyat (KUR). Pembiayaan ini memfasilitasi pembiayaan maksimal Rp10 juta per-usaha dan disalurkan oleh Lembaga Keuangan Bukan Bank (LKBB) dengan bunga pinjaman 2-4 persen.

Pembiayan Ultra Mikro diatur oleh Peraturan Menteri Keuangan No. 95/PMK.05/2018 tentang pembiayaan ultra mikro. Pembiayaan ini disalurkan melalui LKBB yang saat ini salah satu lembaga yang menyalurkan pembiayaan adalah PT. Pegadaian (Persero). Pendanaan ultra mikro bersumber dari APBN, pemerintah daerah dan lembaga-lembaga keuangan domestik dan global. Pembiayaan ultra mikro diluncurkan oleh pemerintah pada tahun 2017 dengan maksud melangkapi program KUR yang telah diluncurkan sebelumnya. Dua tahun setelah peluncuran, pembiayaan ultra mikro telah membantu 177.480 usaha di Provinsi Lampung. Sedangkan secara nasional hingga Juli 2020 telah menjangkau 2.257.021 debitur UMi yang tersebar diseluruh Indonesia (Kementrian Keuangan Republik Indonesia, 2018)

Perbedaan mendasar antara pembiayaan ultra mikro dan kredit usaha rakya adalah pendampingan dan pembinaan. Dengan modal yang ditambah pendampingan dan pembinaan oleh lembaga-lembaga terkait diharapkan usaha ultra mikro dapat meningkatkan produktifitasnya. Selain itu, dengan adanya pendampingan dan pembinaan maka diharapkan pelaku usaha ultra mikro dapat memperluas jaringan usaha dan menjalankan etika bisnis dengan baik.

Keadaan pasar yang sangat fluktuatif. Biaya yang dikeluarkan untuk memperoleh bahan baku (input) dan kemampuan atau daya beli konsumen yang tidak menentu, tidak menyurutkan para pelaku usaha yang ada untuk tetap bertahan walaupun kebanyakan menghentikan usahanya karena mendapatkan beberapa kendala yang bersifat internal seperti kuantitas dan kualitas sumberdaya yang tidak mencukupi, keterbatasan modal fisik, dan standarisasi produk. Permasalahan ini diperparah sejak awal tahun 2020 karena dunia dilanda pandemi virus Covid-19. Beberapa negara membuat kebijakan pembatasan sosial untuk meminimalisir penyebaran virus tersebut. Disamping menimbulkan krisis kesehatan secara global, pandemi ini juga menciptakan disrupsi yang kuat pada sektor perekonomian negara (Handayani, 2007).

Dari sisi supply atau penawaran, kebijakan pembatasan sosial dan work from home berdampak menurunnya jumlah sumber daya manuasia yang berperan dalam kegiatan proses produksi. Sedangkan dari sisi demand atau permintaan kebijakan tersebut berpengaruh terhadap daya beli masyarakat karena penghasilan yang menurun akibat pandemi. Kebijakan yang dibuat pemerintah tersebut berdampak secara langsung maupun tidak terhadap keberlangsungan usaha sektor mikro. Sebelum penerapan kebijakan-kebijakan tersebut omzet para pelaku usaha di Indonesia sudah menunjukkan penurunan. Penurunan omzet tersebut terjadi karena penurunan jumlah konsumen atau pembeli, masyarakat selaku konsumen merasa takut terpapar virus Covid-19 sehingga mengurangi tindakanan konsumsi dan berkegiatan diluar rumah (Thobias, 2013).

Fenomena Covid-19 merupakan hal yang berdampak besar bagi pelaku usaha. Banyak upaya yang telah dilakukan pemerintah dan masyarakat untuk menjalan kan roda perekonomian. Upaya tersebut berupa stimulus bagi sektor usaha kecil, dalam penelitian ini adalah pelaku usaha ultra mikro. Dengan besarnya jumlah belanja dalam negeri yang dilakukan pemerintah diharapkan dapat meningkatkan daya beli masyarakat sehingga perekonomian terus berjalan dengan baik, serta dari sisi investasi usahapun meningkat (Nurhadiono, A. P., \& Tumengkal, 2019)

Modal Sosial Sebagai Upaya Keberlangsungan Usaha Ditengah Pandemi Covid-19 (Studi Kasus Pada Direktur 
Selain stimulus atau modal fisik, modal sosial juga harus dimiliki para pelaku usaha untuk menjalankan usahanya selama pandemi Covid-19. Modal sosial yang dimaksud ialah satu rangkaian norma atau nilai nonformal yang dimiliki bersama antara anggota pada suatu kelompok masyarakat yang saling berkaitan, berdasarkan pada nilai kepercayaan, norma dan jaringan sosial. Modal sosial Modal sosial adalah suatu kapabilitas yang timbul dari kepercayaan di suatu kelompok masyarakat secara umum (Fukuyama, 1995). Menurut (Suryana, 2007) antar pelaku usaha sering timbul suatu kerjasama atau persaingan pada hubungan sosial terjadi diantara mereka. Hal ini yang pada akhirnya memunculkan suatu modal (capital) yang diistilahkan sebagai modal sosial (social capital). Dalam membangun sebuah usaha, modal tidak selalu hanya berupa modal fisik yang berupa barang atau uang, namun dapat juga nodal yang tidak berupa fisik yaitu modal sosial.

Menurut (Putman, 2000) modal sosial merupakan investasi sosial yang mencakup sumber daya sosial yaitu jaringan, kepercayaan, nilai atau norma dalam suatu hubungan sosial untuk memperoleh tujuan kelompok maupun individu seacara efektif dan efisien dengan modal lainnya. Modal sosial memiliki peranan terhadap kelangsungan usaha, khususnya usaha dilapisan ultra mikro. Norma atau nilai merupakan landasan terbentuknya modal sosial karena merupakan dasar dalam terciptanya suatu hubungan timbal balik antara kelompok atau individu. Indikator lain dalam memperkokoh modal sosial ialah kepercayaan yang dibangun dan dikelola bersama-sama. Dengan adanya kepercayaan menjelaskan bahwa terdapat suatu jaringan yang menunjukkan suatu link antar kelompok atau individu yang saling berinterkasi. Hal ini dapat terlihat jelas pada kegiatan usaha ultra mikro, dimana antar pelaku usaha saling berinterkasi dan bekerjasama. Kegiatan kerjasama tersebut berlangsung secara terus menerus antar kelompok dan individu sehingga tumbuh suatu kepercayaan dan jaringan diantara mereka. Selain kepercayaan dan jaringan, norma atau etika bisnis pun sangat penting untuk dimiliki pelaku usaha ultra mikro. Dengan adanya norma yang jelas dan dipatuhi seluruh pelaku usaha, maka akan tercipta lingkungan usaha yang sehat dan secara jangka panjang diharapkan dapat meningkat taraf hidup para pelaku usaha tersebut.

Modal sosial terbentuk menyerupai seperti jaringan sosial yang dibangun berdasarkan kedekatan geografis dan emosional sehingga dapat memudahkan akses dalam memperoleh informasi yang berkenaan tentang pasar (Ferdinand, 2005). Pelaku usaha dapat dengan cepat mendapatkan informasi tentang permintaan konsumen, memonitor kelemahan dan kekuatan pesaing, pelayanan terhadap konsumen, serta periklanan produk sehingga memudahkan pelaku usaha untuk mengembangkan bisnisnya. Mengulas tentang persaingan suatu usaha maka bagaimana pengaruh modal sosial tersebut terhadap proses keberlangsungan usaha yaitu pada proses produksi, pembentukan harga, sampai dengan pemasaran produk (Effendy, 2018).

Menurut hasil penelitian (Pamungkas, L. S., \& Sunaryoto, 2019) diketahui bahwa adanya pengaruh positif antara modal sosial dan prilaku usaha dengan proporsi modal sosial sebesar $79 \%$. Indikator atau unsur modal sosial yang sangat berpengaruh terhadap keberlangsungan usaha ialah kepercayaan atau trust. Begitu pula dengan hasil penelitian (Ciambotti, Massimo \& Pallazi, 2015) pelaku usaha secara sadar memilih untuk berinvestasi dalam modal sosial, karena modal sosial yang tinggi dan berkualitas dapat menciptakan nilai bagi pelaku usaha dan masyarakat luas. Sedangkan hasil penelitian (Fajrina, 2017) menyatakan bahwa variabel modal sosial tidak memiliki pengaruh yang signifikan terhadap keberlangsungan usaha UMKM kuliner di kota Medan.

Menurut (Anderson, A.R., Park, J., \& Jack, 2007) meskipun literatur tentang modal sosial sudah meningkat signifikan dalam beberapa tahun terakhir maka perlu memperjelas konseptual modal usaha dalam keberlangsungan suatu usaha. Temuan penelitian ini menunjukkan bahwa modal sosial merupakan kerangka relasional yang diperoleh dari interkasi dan hubungan sosial, pada suatu jaringan sosial terjadi saling ketergantungan anggota kelompok yang saling menguntungkan ataupun tidak 
saling menguntungkan. Fenomena inilah yang sangat menarik untuk dilakukan penelitian lanjutan, karena pada usaha ultra mikro dalam menjalankan dan mempertahankan usahanya terdapat unsur kepercayaan, jaringan, dan norma. Ketiga indikator yang terdapat pada modal sosial tersebutlah yang menjadi potensi untuk para pelaku usaha ultra mikro mempertahankan dan mengembangkan usahanya. Selain itu, pada penelitian bertujuan menganalisis sejauh mana ketiga indikator modal sosial tersebut berpengaruh terhadap keberlangsungan usaha debitur ultra mikro PT. Pegadaian (Persero) area Lampung. Sedangkan, hipotesis penelitian ini adalah diduga indikator-indikator modal sosial yaitu jaringan, kepercayaan, dan norma berpengaruh positif dan signifikan terhadap keberlangsungan usaha ultra mikro PT. Pegadaian (Persero) area Lampung.

\section{METODE PENELITIAN}

Secara umum pendekatan yang digunakan penelitian ini adalah pendekatan kuantitatif. Penelitian ini menganilisis pengaruh kepercayaan, jaringan, dan norma yang merupakan indikator modal sosial sebagai variabel bebas atau independen terhadap keberlangsungan usaha sebagai variabel terikat atau dependen. Data yang dugunakan pada penelitian ini adalah data primer dengan alat bantu kuisioner.

Metode penentuan sampel adalah metode probability dengan teknik random sampling. Sampel yang digunakan adalah 85 responden dari total debitur aktif pembiayan ultra mikro sebanyak 545 nasabah PT. Pegadaian (Persero) Area Lampung. Data pada penelitian ini dikumpulkan dengan cara menyebarkan kuisioner yang berkaitan sebagai berikut: pengaruh kepercayaan (trust) terhadap keberlangsungan usaha ultra mikro, pengaruh jaringan (network) terhadap keberlangsungan usaha ultra mikro, dan pengaruh norma (norms) terhadap keberlangsungan usaha ultra mikro.

Pengukuran variabel dependen dan independen menggunakan skala likert yang memungkinkan penyebaran nilai jawaban responden. Skala likert adalah variasi dari skala deferensial sematik, dimana skla ini digunakan untuk mengukur karakteristik dan sikap tertentu yang dimiliki responden sehingga data yang didapat berupa data interval (Sugiyono, 2008). Pertanyaan pada kuisioner terstruktur kemudian dimodifikasi melalui daftar petanyaan agar lebih mudah dipahami. Lima alternatif jawaban untuk setiap pertanyaan pada penelitian ini, yaitu: Pernyataan : Sangat tidak setuju 12345 sangat setuju.

Teknik analisis yang digunakan adalah analisis regresi berganda, yaitu mengetahui hubungan secara linier antara dua atau lebih variabel bebas/independen dan variabel terikat/dependen. Persamaan statistik penelitian ini adalah sebagai berikut:

$$
\mathrm{Y}=\mathrm{b}_{0}+\mathrm{b}_{1} \mathrm{X}_{1}+\mathrm{b}_{2} \mathrm{X}_{2}+\mathrm{b}_{3} \mathrm{X}_{3}
$$

Keterangan:

Y : Keberlangsungan usaha

$\mathrm{b}_{0}$ : Koefisien beta

$\mathrm{X}_{1}$ : Kepercayaan

$\mathrm{X}_{2}:$ Jaringan

$\mathrm{X}_{3}:$ Norma

Modal Sosial Sebagai Upaya Keberlangsungan Usaha Ditengah Pandemi Covid-19 (Studi Kasus Pada Direktur Ultra Mikro (UMI) PT. Pegadaian (Persero) Area Lampung, Rini Aprilia, Toto Gunarto dan Ratih Yanti Taher 


\section{HASIL DAN PEMBAHASAN}

Hasil pengujian normalitas dengan menggunakan Kolmogorov-Smirnov Test memperoleh nilai signifikansi 0,725 . Nilai tersebut lebih besar dari 0,05 yang berarti tidak mengalami masalah karena seluruh data terdistribusi secara normal.

Tabel 1.

Hasil Pengujian Normalitas

\begin{tabular}{cccc}
\hline Model & Kolmogorov-Smirnov $Z$ & Probability & Keterangan \\
\hline Unstandardized Residual & 0,592 & 0,725 & Terdistribusi normal \\
\hline Sumber: Data diolah, 2021 & & &
\end{tabular}

Hasil pengujian multikolinieritas mendapatkan nilai tolerance variabel kepercayaan sebesar 0,747, variabel jaringan sebesar 1,034 dan variabel norma sebesar 0,987. Sedangkan untuk nilai VIF variabel kepercayaan sebesar 1,181, variabel jaringan sebesar 3,645, dan variabel norma sebesar sebesar 2,001. Dari angka tersebut didapat bahwa data penelitian ini tidak terjadi masalah multikolinieritas karena nilai tolerance dan VIF semua variabel tidak lebih dari 10.

Tabel 2.

Hasil Pengujian Multikolinieritas

\begin{tabular}{lrrl}
\hline \multicolumn{1}{c}{ Variabel } & Tolerance & \multicolumn{1}{c}{ VIF } & \multicolumn{1}{c}{ Keterangan } \\
\hline Kepercayaan & 0,747 & 1,181 & Tidak terjadi multikolinieritas \\
Jaringan & 1,034 & 3,654 & Tidak terjadi multikolinieritas \\
Norma & 0,987 & 2,001 & Tidak terjadi multikolinieritas \\
\hline
\end{tabular}

Sumber: Data diolah, 2021

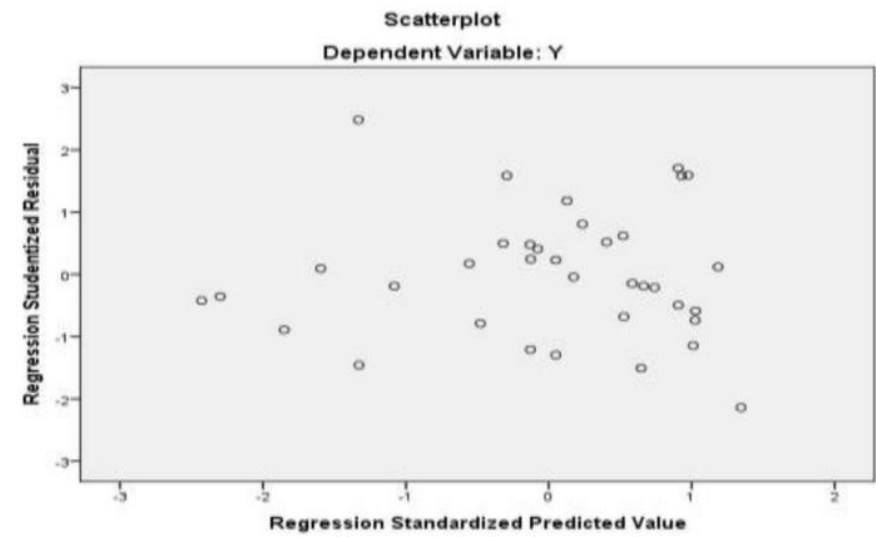

Sumber: Data diolah, 2021

Gambar 1.

Hasil Pengujian Heteroskedastisitas

Hasil pengujian hipotesis menunjukkan bahwa kepercayaan, jaringan serta norma berpengaruh positif dan signifikan terhadap keberlangsungan usaha ultra mikro. Hal ini ditunjukkan oleh nilai $\mathrm{F}-\mathrm{h}_{\text {itung }}$ sebesar 50,527 pada tingkat signifikansi 0,000 dengan tingkat kepercayaan yang ditentukan sebesar 5\%. Hal ini menunjukkan bahwa semakin tinggi tingkat kepercayaan, jaringan dan 
norma-norma yang ada semakin tinggi tingkat keberlangsungan usaha debitur ultra mikro PT. Pegadaian (Persero) area Lampung. Berdasarkan hasil pengujian diperoleh persamaan regresi linier berganda sebagai berikut:

$$
\mathrm{Y}=(0,643)+0,717 \mathrm{X}_{1}+0,341 \mathrm{X}_{2}+0,987 \mathrm{X}_{3}+\mathrm{e}
$$

Keterangan:

Y : Keberlangsungan usaha

$\mathrm{X}_{1}$ : Kepercayaan

$\mathrm{X}_{2}$ : Jaringan

$\mathrm{X}_{3}$ : Norma

Tabel 3.

Hasil Pengujian Regresi Berganda

\begin{tabular}{lcccc}
\hline \multicolumn{1}{c}{ Variabel } & Koefisien regresi (b) & T-hitung $_{\text {- }}$ & Signifikansi & Keterangan \\
\hline Konstanta & $-0,643$ & & & \\
Kepercayaan & 0,717 & 4,281 & 0,000 & Berpengaruh signifikan \\
Jaringan & 0,341 & 5,243 & 0,000 & Berpengaruh signifikan \\
Norma & 0,987 & 1,376 & 0,000 & Berpengaruh signifikan \\
\hline Sumber: Data diolah, 2021 & & & &
\end{tabular}

Hasil pengujian determinasi mendapatkan nilai adjusted $\mathrm{R}^{2}$ sebesar 0,779 , Hal ini menunjukkan bahwa tingkat keberlangsungan usaha debitur ultra mikro PT. Pegadaian (Persero) area Lampung dapat dijelaskan sebesar $77,9 \%$ oleh variabel independen yaitu variabel kepercayaan, jaringan serta norma-norma. Sedangkan sisanya $22,1 \%$ variasi tingkat keberlangsungan usaha debitur ultra mikro PT. Pegadaian (Persero) area Lampung dijelaskan oleh variabel-variabel diluar variabel independen penelitian ini.

Tabel 4.

Hasil Pengujian $\mathbf{R}^{2}$

\begin{tabular}{ccc}
\hline$R$ & $R$ Square & Adjusted $R$ Square \\
\hline 0,509 & 0,725 & 0,779 \\
\hline
\end{tabular}

Sumber: Data diolah, 2021

Tabel 5.

Hasil Pengujian Simultan

\begin{tabular}{rrr}
\hline F-Hitung & Signifikansi & Keterangan \\
\hline 15,641 & 0,000 & Berpengaruh simultan \\
\hline
\end{tabular}

Sumber: Data diolah, 2021

Hasil pengujian simultan atau uji $\mathrm{F}$ diperoleh $\mathrm{F}_{\text {-hitung }}$ sebesar 15,641 yang lebih besar dari nilai $\mathrm{F}_{\text {-tabel }}$ sebesar 2,480, dan nilai signifikansi 0,000. Artinya menyimpulkan bahwa $\mathrm{H}_{0}$ ditolak atau $\mathrm{H}_{1}$ diterima., dengan demikian dapat dikatakan bahwa variabel kepercayaan, jaringan, dan norma berpengaruh secara bersama-sama terhadap keberlangsungan usaha debitur ultra mikro PT Pegadaian (Persero) area Lampung.

Modal Sosial Sebagai Upaya Keberlangsungan Usaha Ditengah Pandemi Covid-19 (Studi Kasus Pada Direktur Ultra Mikro (UMI) PT. Pegadaian (Persero) Area Lampung, Rini Aprilia, Toto Gunarto dan Ratih Yanti Taher 
Pengujian parsial atau Uji-T merupakan suatu uji untuk mengetahui pengaruh secara parsial untuk masing-masing variabel independen yaitu dengan cara membandingkan nilai $\mathrm{T}_{\text {-hitung }}$ dengan $\mathrm{T}_{\text {-table. }}$. Selain itu juga dengan melihat dari nilai signifikansi dan membandingkannya dengan tingkat signifikansi sebesar 0,05. Dari hasil penelitian yang dilakukan disimpulkan bahwa $\mathrm{H}_{0}$ ditolak atau $\mathrm{H}_{1}$ diterima untuk masing-masing variabel. Artinya, variabel kepercayaan, jaringan, dan norma masing-masing berpengaruh signifikan terhadap keberlangsungan usaha debitur ultra mikro PT. Pegadaian (Persero) area Lampung.

Tabel 6 .

Hasil Uji T

\begin{tabular}{lccc}
\hline \multicolumn{1}{c}{ Variabel } & T-Hitung & Signifikansi & Keterangan \\
\hline Kepercayaan & 4,764 & 0,000 & Berpengaruh signifikan \\
Jaringan & 1,980 & 0,010 & Berpengaruh signifikan \\
Norma & 2,223 & 0,000 & Berpengaruh signifikan \\
\hline
\end{tabular}

Sumber: Data Diolah, 2021

Variabel kepercayaan (trust) memiliki nilai $\mathrm{T}_{\text {-hitung }}$ sebesar 4,764 dan $\mathrm{T}_{\text {-tabel }}$ sebesar 1,292, dan tingkat signifikansi sebesar 0,000 . Hal ini menunjukkan $\mathrm{T}_{\text {-hitung }}$ lebih besar dari $\mathrm{T}$-tabel dan nilai signifikansi lebih kecil dari 0,05 , sehingga $\mathrm{H}_{0}$ ditolak atau $\mathrm{H}_{1}$ diterima. Ini menunjukkan variabe kepercayaan berpengaruh secara signifikan terhadap keberlangsungan usaha debitur ultra mikro PT. Pegadaian (Persero) area Lampung. Semakin tinggi tingkat kepercayaan atau rasa saling percaya antar pelaku usaha maka semakin baik pula perkembangan usaha yang dijalankan.

Kepercayaan tercipta tidak dengan seketika akan tetapi membutuhkan proses dari hubungan diantara kelompok atau individu yang sudah menjalani beberapa periode waktu dalam melalukan tindakan ekonomi secara bersama-sama. Kepercayaan akan timbul dengan adanya sikap yang saling disiplin dan jujur terhadap aturan atau nilai yang telah disepakati. Kepercayaan tersebut memiliki fungsi antara lain untuk menjaga ketertiban, meminimalkan biaya produksi dan transaksi, mendorong pelaku usaha dalam menggambil keputusan yang tepat, mempererat hubungan produsen dan konsumen, menimbulkan kerjasama sehingga dapat menyederhanakan pekerjaan, memperluas jaringan, dan yang utama adalah kepercayaan merupakan aset penting dalam menciptakan modal sosial.

Salah satu bentuk kepercayaan antar pelaku usaha adalah dalam hal hutang-piutang stok barang dagangan. Hal ini dikarenakan dinamika usaha yang naik turun, kegiatan atau transaksi hutang-piutang stok barang ini dirasakan bermanfaat diantara para pegadang yang keterbatasan modal. Keuntungan yang dirasakan oleh semua pihak yaitu pemberi pinjaman mendapatkan manfaat yaitu terhindar dari tumpukan stok karena dapat menyalurkan secara berkala. Sedangkan yang mendptkan pinjaman mendapatkan manfaat yaitu mendapatkan stok untuk menjalankan usahanya tanpa memiliki modal tunai terlebih dahulu, sehingga proses roduksi terus berjalan dan mendaptkan keuntungan. Dengan adanya transaksi hutang-piutang stok barang ini para pedagang sudah memupuk dan membina sikap saling percaya dan bekerja sama untuk mendapatkan tujuan yang sama yaitu keuntungan dari usaha yang mereka jalani. Selain kepercayaan antar pelaku usaha, penelitian ini juga mengidentifikasi sejauh mana kepercayaan pelaku usaha selaku debitur terhadap PT. Pegadaian (Persero) selaku kreditur. Hasil survei menyebutkan bahwa para debitur percaya bahwa dengan adanya stimulus atau bantuan modal yang mereka terima dapat mengembangkan usaha yang sudah mereka jalani.

Modal Sosial Sebagai Upaya Keberlangsungan Usaha Ditengah Pandemi Covid-19 (Studi Kasus Pada Direktur Ultra Mikro (UMI) PT. Pegadaian (Persero) Area Lampung, Rini Aprilia, Toto Gunarto dan Ratih Yanti Taher 
Penelitian (Sani, Habibu, Khan, S. M., \& Noor, 2019) mengungkapkan tantangan besar yang dihadapi sektor usaha kecil dan mikro sebagai akibat dari kesulitan dalam mengakses keuangan, kekurangan infrastruktur, akumulasi modal, tabungan pribadi yang tidak memadai, pengalaman yang rendah, dan teknologi inovatif. Temuan penelitian ini menunjukkan modal sosial yang diproksikan kepercayaan memiliki pengaruh yang positif terhadap keberlangsungan usaha kecil di negara berkembang.

Variabel jaringan memiliki nilai $\mathrm{T}_{\text {-hitung }}$ sebesar $1,920, \mathrm{~T}_{\text {-tabel }}$ sebesar 1,292, dan tingkat signifikansi sebesar 0,010. Hal ini menunjukkan $\mathrm{T}_{\text {-hitung }}$ lebih besar dari $\mathrm{T}_{\text {-tabel }}$ dan nilai signifikansi lebih kecil dari 0,05 , sehingga $\mathrm{H}_{0}$ ditolak atau $\mathrm{H}_{1}$ diterima. Ini menunjukkan jaringan berpengaruh terhadap keberlangsungan usaha debitur ultra mikro PT. Pegadaian (Persero) area Lampung. Semakin luas jaringan kerja dan sosial yang dimiliki seorang atau kelompok pelaku usaha maka semakin baik pula perkembangan usaha yang dijalankan.

Dengan adanya jaringan para pelaku usaha akan saling membantu baik dalam hal pengembangan usaha ataupun penyelesaiaan konflik. Jaringan antar pelaku usaha biasanya terjadi dalam rangka perolehan sumber daya atau barang dagangan, kemudahan atau keringanan yang sering terjadi adalah dalam proses pembayaran. Pelaku usaha yang menginginkan suatu sumber daya tidk perlu melakukan pembayaran secara lansung saat pembelian tapi dapat dengan fasilitas jaringan seperti dana kas paguyuban yng dapat digunakan sementara waktu. Dengan adanya fasilitas dari jaringan tersebut dapat dikatakan bahwa jaringan memiliki peranan penting dalam perkembangan usaha anggota kelompoknya. Dilain sisi, peluang usaha baru dapat tercipta dengan adanya jaringan, yaitu melalui akses pertemanan, kolega, serta kekerabatan antar anggota jaringan tersebut. Dengan terbukanya peluang usaha tersebut maka akan ada jaminan ketersediaan sumber daya atau barang, membuka informasi harga dari pelanggan, menjaring pelanggan baru, diversifikasi produk sesuai keinginan konsumen, bahkan dalam penyelesaian konflik apabila hubungan relasi tersebut terjaga dengan baik. Dengan banyaknya keuntungan yang diperoleh dari jaringan atau relasi, maka akan ada jaminan untuk suatu usaha berlangsung dengan baik dan lancar. Dengan demikian pentingnya jaringan bagi pelaku usaha, maka segala upaya dilakukan agar hubungan relasi yang sudah ada terus berlangsung dan serta membangun pula hubungan relasi yang baru untuk menciptakan jaringan yang kokoh.

Menurut hasil penelitian (Nurhadiono, A. P., \& Tumengkal, 2019) melalui jaringan para pengusaha akan saling membantu dan bertukar informasi, sehingga dapat membantu keringan biaya dalam transaksi. Kepercayaan muncul karena adanya sikap untuk menjalankan norma yang diciptakan untuk kepentingan bersama. Dengan kejujuran dan kedisiplinan menjalankan norma maka dapat memperlancar keberlangsungan usaha. Unsur modal sosial berupa kepercayaan memiliki peran dalam pemenuhan bahan baku dan penjualan. Dalam hal pemenuhan bahan baku kepercayaan dengan pemasok telah berhasil membuat transaksimenjadi lebih lancar dan transparan, sedangkan dari sisi penjualan kepercayaan terhadap karyawan modal utama untuk memenuhi kebutuhan pelanggan. Unsur jaringan yang terjalin dengan pelanggan dapat memberikan manfaat penyaluran informasi dan promosi sehingga mendukung keberlangsungan usaha.

Bedasarkan hasil survei pada penelitian ini para pelaku usaha ikut aktif dan partisipatif dalam suatu kegiatan yang diadakan kelompok baik kegiatan formal ataupun informal. Seperti yang dijelaskan sebelumnya, pembiayaan ultra mikro memiliki kelebihan dibandingkan pembiayaan lainnya yaitu pembinaan dan pendampingan yang dilakukan kreditur.

Variabel norma memiliki nilai $\mathrm{t}_{\text {-hitung }}$ sebesar 2,223, $\mathrm{t}_{\text {-tabel }}$ sebesar 1,292, dan tingkat signifikansi sebesar 0,000 . Hal ini menunjukkan $\mathrm{T}_{\text {-hitung }}$ lebih besar dari $\mathrm{t}_{\text {tabel }}$ dan nilai signifikansi lebih kecil dari 0,05 , sehingga $\mathrm{H}_{0}$ ditolak dan $\mathrm{H}_{1}$ diterima. Ini menunjukkan norma berpengaruh 
terhadap keberlangsungan usaha debitur ultra mikro PT. Pegadaian (Persero) area Lampung. Semakin tinggi norma-norma atau etika bisnis dijalankan antar pelaku usaha maka semakin baik pula perkembangan usaha yang dijalankan.

Norma atau nilai yang ada dimasyarakat dapat bersifat formal maupun informal. Suatu bentuk perjanjian usaha tertulis yang disepakati oleh masing-masing pihak merupakan bentuk formal dari suatu norma. Sedangkan kesepakan yang tidak tertulis atau hanya dengan ucapan kesepakatan antar pelaku usaha merupakan bentuk norma informal. Contoh norma informal dalam berwirausaha atau berdagang dilakukan antar konsumen dan penjual atau penjual dan penjual dalam menentukan kesepakatan harga, kesepakatan bentuk atau sistem pembayaran. Ketaatan dalam pembayaran sesuai kesepakatan merupakan sikap mentaati aturan dalam suatu kegiatan perekonomian. Dengan norma yang terjaga antar pelaku usaha maka akan tercipta lingkungan bisnis yang baik dan meninimalisir konflik antar pelaku usaha. Bedasarkan hasil penelitian para pelaku usaha berusaha menjalankan usahannya sesuai dengan ketentuan atau norma yang diberlakukan. Dengan adanya norma atau etika dalam menjalankan usaha maka penyimpangan prilaku dapat diminimalkan, sehingga terciptanya keamanan, kenyamanan, dan kelancaran usaha.

Penelitian (Hoq, M.Z., Wirba, A.F., Baiq, 2017) mengungkapkan adanya hubungan positif antara modal sosial dan keberlangsungan usaha. Disini, modal sosial memainkan fungsi utama dalam usaha kecil dan mikro untuk mencapai tujuan bisnis mereka. Selain itu, diketahui bahwa modal sosial memiliki hubungan yang substansial dengan keberlangsungan suatu usaha. Hasilnya, penelitian ini mendorong agar usaha mikro melakukan pengendalian untuk mendorong, membangun, dan menegakkan jejaring sosial, norma dan kepercayaan yang layak guna mengembangkan keuntungan yang lebih besar.

Sumber daya strategis untuk implementasi keberlanjutan usaha kecil dan mikro merupakan sifat yang relasional. Hal ini yang menjadikan modal sosial menjadi hal menarik perhatian dan menekankan peran strategisnya yang signifikan sehingga dapat memperkuat sumber daya relasional mereka. Dengan demikian, modal sosial merupakan penghubung penting dan keterlibatan pemangku kepentingan di antara pendekatan terbaik untuk perkembangan dan keberlanjutan di perusahaan kecil dan mikro. Sangat penting bagi kecil dan mikro untuk menjadi bagian dari jaringan bisnis mengingat dampaknya yang semakin besar pada strategi membangun hubungan. Keberlanjutan dalam jaringan ini merupakan konsepsi mereka hingga motivasi dan kondisi yang mendasari untuk sukses. Ini juga mengidentifikasi kebutuhan untuk membangun hubungan antara modal sosial bisnis, daya saing sistem produktif dan kelembagaan untuk menciptakan jaringan berkelanjutan yang "unik" yang membawa karakteristik ekonomi dan budaya dari konteks lokalnya (De Chiara, 2017).

\section{SIMPULAN DAN SARAN}

Masing-masing indikator modal sosial yaitu kepercayaan, jaringan, dan norma berpengaruh positif dan signifikan terhadap keberlangsungan usaha debitur ultra mikro PT. Pegadaian (Persero) area Lampung. Ketiga indikator modal sosial tersebut secara bersama-sama berpengaruh signifikan terhadap keberlangsungan usaha debitur ultra mikro PT. Pegadaian (Persero) area Lampung. Melihat permasalahan keberlangsungan usaha, maka modal sosial dapat dipupuk secara formal dengan membentuk kelompok atau paguyuban para pelaku usaha untuk menampung dan memfasilitasi komunikasi dan informasi yang baik. Dalam meningkatakan modal sosial dibutuhkan kepekaan dan upaya untuk menciptakan hubungan dengan orang perorang atau kelompok dengan kelompok yang saling siap membantu baik dalam hal masalah keuangan/permodalan ataupun hal lainnya. Upaya utama yang dilakukan adalah memperkokoh bidang kelembagaan sosial ekonomi masyarakat sebagai

Modal Sosial Sebagai Upaya Keberlangsungan Usaha Ditengah Pandemi Covid-19 (Studi Kasus Pada Direktur Ultra Mikro (UMI) PT. Pegadaian (Persero) Area Lampung, Rini Aprilia, Toto Gunarto dan Ratih Yanti Taher 
dasar modal sosial dalam pembangunan. Hal itu perlu dilakukan upaya selalu memperkuat kelembagaan sosial ekonomi masyarakat sebagai modal sosial dalam pembangunan, dan upaya-upaya tersebut antara lain: 1. Memperbaiki fungsi dan struktur kelembagaan di masyarakat, 2. Memanfaatkan teknologi dan informasi yang berimbang, 3. Meningkatkan pembinaan dan pendampingan secara berkelompok dan berstruktur, 4. Memperbaiki dan menambahkan pembangunana sarana prasarana aktifitas kelembagaan, 5. Memfasilitasi dan memberdayakan kelembagaan informal, 6. Membentuk pemimpin kelembagaan yang transparan dan profesional.

Bagi Pelaku usaha, agar dapat bersikap terbuka kepada sesama agar tetap menjaga hubungan baik sehingga dapat meningkatkan modal sosial. Selain itu para pelaku usaha diharapkan turut aktif dan partisipatif dalam segala kegiatan atau perkumpulan yang diadakan kelompok atau lembaga terkait.

\section{REFERENSI}

Anderson, A.R., Park, J., \& Jack, S. (2007). Enterpreneurial Social Capital Conceptualizing Social Capital in New High-tech Firms. International Small Business Journal. International Small Business Journal, 25(3), 1-20. https://doi.org/https://doi.org/10.1177/0266242607076526

Ciambotti, Massimo \& Pallazi, F. (2015). Social Capital and SMEs: An Exploratory Case Study. Journal Of International Business And Economics, 15(2), 53-64.

De Chiara, A. (2017). Implementing sustainability strategies in networks and cluster, CSR, sustainability, ethics and governance. Www.Amazon.Com.

Effendy, J. (2018). Peran Modal Sosial Sebagai Upaya Pengembangan UMKM Di Desa Batu Merah Kota Ambon. Cita Ekonomika, Jurnal Ekonomi, 12(2), 103-108.

Fajrina, R. (2017). Pengaruh Entrepreneurial Intellectual Capital Terhadap Kinerja UMKM Kuliner Asia Mega Mas Medan. Universitas Sumatera Utara.

Ferdinand, A. T. (2005). Modal Sosial dan Keunggulan Bersaing: Wajah Sosial Strategi Kinerja Pemasaran, Disampaikan pada Upacara Persemian Penerimaan Jabatan Guru Besar dalam Ilmu Marketing pada Fakultas Ekonomi Universitas Diponegoro.

Fukuyama, F. (1995). Trust: The Sosial Virtues and The Creation of Prosperity. Free Press.

Handayani, N. (2007). Modal Sosial Dan Keberlangsungan Usaha (Studi Deskriptif Kualitatif Tentang Keterkaitan Hubungan Modal Sosial Dengan Keberlangsungan Usaha Pengusaha Batik Di Kampung Kauman, Kelurahan Kauman, Kecamatan Pasar Kliwon, Surakarta). Universitas Sebelas Maret Surakart.

Hoq, M.Z., Wirba, A.F., Baiq, A. (2017). ). Social Capital and Small Medium Enterprise (SME) Performance: An Exploratory Study. International Journal of Novel Research in Marketing Management and Economics, 4(1), 33-39.

Kementrian Keuangan Republik Indonesia. (2018). Peraturan Menteri Keuangan Nomor 95/PMK.05/2018 tentang pembiayaan ultra mikro.

Nurhadiono, A. P., \& Tumengkal, S. M. (2019). Modal sosial dan keberlangsungan usaha pegadang sayuran di pasar bersehati Manado. E-Journal Universitas Sam Ratulangi, 12(4), 1-20.

Pamungkas, L. S., \& Sunaryoto, L. T. (2019). Analysis Of The Social Capital Ownership Impact Against The Sustainability Of Small Industry In Niswa's Restaurant. Jurnal Sosial Ekonomi Pertanian, 15(1), 71-80.

Putman, R. D. (2000). Bowling Alone: The Collapse and revival of Amerika Community. Simon and Schuter.

Sani, Habibu, Khan, S. M., \& Noor, M. S. Z. (2019). Do Social Capital and Small and Medium Enterprise Factors Influence the Performance of Small Businesses? Empirical Evidence from Emerging Economy. Journal Or Economic Studies, 5(4), 78-87.

Sugiyono. (2008). Metode Penelitian Bisnis. Alfabeta.

Suryana, B. (2007). Kewirausahaan pedoman praktis kiat dan proses menuju sukses. Salemba Empat.

Thobias, E. (2013). Pengaruh modal sosial terhadap perilaku kewirausahaan (Suatu studi pada pelaku usaha mikro kecil menengah di Kecamatan Kabaruan Kabupaten Kepulauan Talaud). Jurnal Acta Diurna, 2(2), $1-12$. 